ISSN : 0216-3160 EISSN : 2252-3901

\title{
JURNAL TEKNOLOGI INDUSTRI PERTANIAN
}

\author{
Vol. 29, No. 1, 2019
}

Penanggung Jawab

Ketua Umum Asosiasi Agroindustri Indonesia dan Ketua Departemen Teknologi Industri Pertanian, FATETA - IPB

\section{Ketua Dewan Editor \\ Marimin (IPB)}

\section{Dewan Editor}

Agus H. Canny (AGRIN)

Didik Purwadi (UGM)

Dwiwahju Sasongko (ITB)

Kadarsah Suryadi (ITB)

M.Syamsul Ma'arif(IPB)

Moses L. Singgih (ITS)

Tajuddin Bantacut (IPB)

N. Taufiqurahman (LIPI)

\section{Editor Pelaksana}

Ika Amalia Kartika (Ketua)

Andes Ismayana

Dwi Setyaningsih

Ono Suparno

Titi Candra Sunarti

\section{Sekretariat}

Sri Martini

Ketih Suketih

Teguh Adisetia

\section{Penerbit}

Asosiasi Agroindustri Indonesia (AGRIN) dan Departemen Teknologi Industri Pertanian (TIN) Fakultas Teknologi Pertanian (FATETA) Institut Pertanian Bogor (IPB)

\author{
Alamat Redaksi \\ Departemen Teknologi Industri Pertanian \\ Fakultas Teknologi Pertanian \\ Institut Pertanian Bogor \\ Jln. Kamper, Kampus IPB Darmaga, Bogor 16680 \\ Telp./Fax. (0251) 8621974, 8625088 \\ E-mail: jurnal_tip@yahoo.co.id, \\ tipjurnal@gmail.com atau jurnal_tip@ipb.ac.id
}

\section{Biaya langganan per tahun}

Perorangan Rp.200.000,-

Institusi Rp. 250.000,- belum termasuk ongkos kirim

\section{Permintaan langganan di kirim ke:}

Redaksi Jurnal Teknologi Industri Pertanian

Departemen Teknologi Industri Pertanian,

FATETA-IPB

Kampus IPB Darmaga PO Box 220 Bogor 16002

Telp./Fax. : 0251-8625088 dan 0251-8621974

E-mail: jurnal_tip@yahoo.co.id, tipjurnal@gmail.com atau jurnal_tip@ipb.ac.id

Bank BNI Capem Darmaga, Bogor

No.Rekening: 0275671500 atas nama Ketih Suketih

\section{PRAKATA}

Pembaca yang budiman,

Puji syukur kita panjatkan kehadirat Allah SWT, atas berkat dan rahmatNya kamidapat kembali hadir untuk menyajikan artikel-artikel terkini pada Jurnal Teknologi Industri Pertanian Volume 29 Nomor 1 Edisi April, Tahun 2019.

Semua artikel yang dimuat pada Jurnal Teknologi Industri Pertanian ini telah diseleksi dan ditelaah oleh Dewan Editor dan Mitra Bebestari yang kompeten. Hanya artikel-artikel berkualitas baik dan sangat baik yang dapat dimuat pada Jurnal Teknologi Industri Pertanian.

Topik-topik yang disajikan pada edisi ini meliputi: Strategi peningkatan keberlanjutan agroindustri sayur potong, penentuan kualitas degummed bleached palm oil (DBPO) dan refined bleached deodorized palm oil (RBDPO), pengendalian mutu statistik produk akhir paperboard, analisis kinerja rantai pasok agroindustri kakao di kabupaten Lima Puluh Kota, karakteristik mikrokapsul antosianin ubi jalar ungu, aplikasi perlakuan pendahuluan pulsed electric field (PEF) pada ekstraksi tanin biji pinang, produksi bioetanol dari buah beberapa jenis mangrove di papua, sistem pendukung keputusan cerdas kesesuaian lahan dengan jenis tanaman, pemanfaatan anggur laut (Caulerpa recemosa) dalam pembuatan sup krim instan, analisis dan mitigasi risiko rantai pasok minyak pala, analisis model regresi sedimen kolam lele, sukrosa, dan biofertilizer. Sebagai penutup disajikan artikel yang berjudul produksi film biomulsa dari klobot jagung - LLDPE

Kepada penulis dan mitra bebestari yang telah berkontribusi pada penerbitan jurnal edisi ini, kami menyampaikan terima kasih yang mendalam. Kami mengundang rekan sejawat peneliti dan praktisi agroindustri mengirimkan naskah untuk disajikan pada jurnal ini. Saran dan kritik yang membangun dari pelanggan, pembaca dan para pihak lainnya sangat kami harapkan. Selamat membaca.

Ketua Dewan Editor

Marimin 